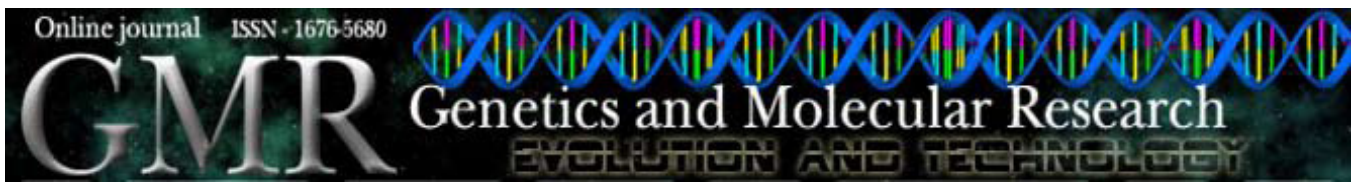

\title{
Species-specific AFLP markers for identification of Zingiber officinale, Z. montanum and Z. zerumbet (Zingiberaceae)
}

\author{
S. Ghosh ${ }^{1}$, P.B. Majumder ${ }^{2}$ and S. Sen Mandi ${ }^{1}$ \\ ${ }^{1}$ Bose Institute, Kolkata, India \\ ${ }^{2}$ Assam University, Silchar, Assam, India \\ Corresponding author: S. Sen Mandi \\ E-mail: swatism@bosemain.boseinst.ac.in/senmandi.swati@gmail.com
}

Genet. Mol. Res. 10 (1): 218-229 (2011)

Received November 17, 2010

Accepted December 6, 2010

Published February 8, 2011

DOI 10.4238/vol10-1gmr1154

\begin{abstract}
The Zingiber genus, which includes the herbs known as gingers, commonly used in cooking, is well known for its medicinal properties, as described in the Indian pharmacopoeia. Different members of this genus, although somewhat similar in morphology, differ widely in their pharmacological and therapeutic properties. The most important species of this genus, with maximal therapeutic properties, is Zingiber officinale (garden ginger), which is often adulterated with other lesspotent Zingiber sp. There is an existing demand in the herbal drug industry for an authentication system for the Zingiber $\mathrm{sp}$ in order to facilitate their commercial use as genuine phytoceuticals. To this end, we used amplified fragment length polymorphism (AFLP) to produce DNA fingerprints for three Zingiber species. Sixteen collections (six of $Z$. officinale, five of $Z$. montanum, and five of $Z$. zerumbet) were used in the study. Seven selective primer pairs were found to be useful for all the accessions. A total of 837 fragments were produced by these primer pairs. Species-specific markers were identified for all three Zingiber species (91 for Z. officinale, 82 for Z. montanum, and 55 for Z. zerumbet). The dendogram analysis generated from AFLP patterns showed that $Z$. montanum and $Z$. zerumbet are phylogenetically closer to each other than to Z. officinale. The AFLP fingerprints of the Zingiber species could be
\end{abstract}


used to authenticate Zingiber sp-derived drugs and to resolve adulterationrelated problems faced by the commercial users of these herbs.

Key words: DNA fingerprinting; AFLP; Zingiber spp; Adulteration; Molecular marker

\section{INTRODUCTION}

Since ancient times, the Zingiberous plants, curcuma and ginger, have been recognized as medicinally valuable. References of these plants are found in all systems of Indian traditional and folk medicine. Classic/taxonomic grouping of these plants has often caused confusion. About 50 genera and 1300 species of ginger species/varieties are known to exist worldwide. The plants occur mainly in Australia, Bangladesh, Haiti, Jamaica, Japan, Nigeria, Srilanka, and other south east Asian countries. In India, the indigenous species grow wild in the Western Ghat region particularly in the Malabar coasts of Kerala. Selected species within this group of plants are cultivated on a large scale in warm and moist regions, mainly around Chennai, Cochin, Himachal Pradesh, Meghalaya, Sikkim, Assam, Arunachal Pradesh, and to a lesser extent in Orissa, Uttar Pradesh (Nainital). In West Bengal these plants are cultivated in the plains as well as in the Darjeeling Hills.

Being vegetatively propagated by rhizomes, which constitute the part of medicinal importance, such plants run the risk of overexploitation in the wild. Notwithstanding cultivated varieties that stand protected from such loss, it is important to explore document and conserve the wild genotypes/land races that may possess valuable medicinal potential and/or stress tolerance genes.

Zingiber officinale Roscoe is a perennial herb belonging to the Zingiberaceae family. It is the most common ginger species in India and it is grown all over the country. The rhizome is horizontal, branched, fleshy, aromatic, white or yellowish to brown, which are generally effective in stomach disorders such as colic, spasms, vomiting, dyspepsia, flatulence, and other painful disorders. It accumulates high levels of important pharmacologically active metabolites, viz., [6]-gingerols, which are some of the products of the phenylpropanoid pathway. The other constituents in Z. officinale are the pungent vanilloids, and [6]-paradol. [6]-Gingerol is a biologically active component that may make a significant contribution towards medicinal applications of ginger and some products derived from ginger. The antioxidant, antitumor, and anti-inflammatory pharmacologic effects of ginger are mainly due to its pungent constituents (e.g., [6]-gingerol). Chewing a fresh ginger piece helps reduce these ailments. The rhizomes are also an effective remedy for cold and cough.

Zingiber montanum (J. Koeing) Link ex A. Dietr is a native of tropical Asia. In India it is found in Arunachal Pradesh, Assam, Sikkim, and Meghalaya. The plant has been proven to be extremely useful for human health and thus developed into creams and massage oils for relieving muscle pain. Furthermore, it is well known that the essential oils from Z. montanum have also been shown to cure acne, bruises, skin burns, skin inflammation, muscle pain, insect bite, and asthmatic symptoms. They are even proven to help cope with cough and respiratory symptoms as well. Rhizome extracts exhibit anti-inflammatory and anti-bacterial activities. A number of pure compounds isolated from the plants have been shown to possess anti-microbial, anti-inflammatory, analgesic, anti-tyrosinase, and anti-oxidative activities. It is also considered to have properties such as analgesic, anti-neuralgic, anti-inflammatory, antiseptic, antispasmodic, antitoxic, anti-viral, carminative, digestive, diuretic, febrifugal, laxative, rubefacient, stimulant, tonic, and vermifugal, and it has been used for aches and pains, asthma, chronic colds, colic, constipation, diarrhea, fevers, flatulence, heartburn, immune problems, inflammation, influenza, joint problems, 
muscle spasms, nausea, respiratory problems, sprains and strains, and torn muscles and ligaments. Zingiber zerumbet (L.) Roscoe ex Sm, also known as the "shampoo-ginger", is a vigorous ginger with leafy stems growing to about $1.2 \mathrm{~m}$ tall. This plant, originating in India, was distributed east-ward through Polynesia and introduced to the Hawaiian Islands in the canoes of early Polynesian settlers. For a toothache or a cavity, the cooked and softened Awapuhi rhizome is pressed into the hollow and left for as long as needed. To ease a stomach ache, the ground and strained rhizome material is mixed with water and drunk. Similarly, Awapuhi Pake is widely cultivated and eaten, or made into a tea for indigestion as well as increased circulation of the blood and to increase sense of well-being. An extract from Z. zerumbet, "Zerumbone", has been found to induce apoptosis, or programmed cell death, in human liver cancer cells.

Of the plants described above, Z. montanum and Z. zerumbet are morphologically almost identical. It is even almost impossible for classical taxonomists to differentiate between these two species in the non-flowering stage. Such life cycle/season-based difficulty in plant identification, through conventional morphological parameters, calls for more precise parameters of plant identification, viz., DNA fingerprinting patterns that provide the ultimate in individualization due to the stability of DNA in any plant part and also through variation in environment and also variation in phase of life cycle. DNA fingerprinting patterns thus provide a yardstick for precise identification of plants and for delimiting possible mixing of similar looking/named plants wittingly or unwittingly by plant collectors/vendors. Production of medicines from precisely selected prescribed plants through the use of DNA characterization protocols would ensure uniform efficacy of medicines produced in different batches.

Other important uses of DNA fingerprinting methods for the development of speciesspecific markers include the establishment of sovereignty rights of plant genetic resources, which is essential under the benefit-sharing regime of the Convention of Biological Diversity (CBD). Under the WTO regime, it is becoming increasingly important to develop passport data of plants to be exported, a need of universal concern particularly considering that the global herbal drug market is expected to grow to US $\$ 5$ trillion by the year 2050 (Joshi et al., 2004).

Amplified fragment length polymorphism (AFLP) is a novel DNA fingerprinting technique that allows DNA characterization under stringent experimental conditions, thus allowing precision. This method also allows the examination of large segments of the DNA in each experiment thus helping to explore the entire genome within a short span of time. Thus, AFLP is a useful method for precise identification of genotype within a short period of time. This method also proves to be very important in plant taxonomy for species-specific identification (Lin et al., 1996, soybean; Waugh et al., 1997, barley; Degani et al., 2001, strawberry; Saunders et al., 1999, 2001, marijuana and opium, respectively; Percifield et al., 2007, Hypericum perforatum L.; Misra et al., 2010, Swertia sp).

The present study was undertaken to generate AFLP-based DNA markers for three species of the Zingiber genus (Z. officinale Roscoe, Z. montanum (J. Koeing) Link ex A. Dietr and $Z$. zerumbet (L.) Roscoe ex Sm). These plants are most commonly used in the herbal trade.

\section{MATERIAL AND METHODS}

\section{Plant materials}

The plant materials used in this study were collected from different parts of eastern and northeastern India, viz., West Bengal, Sikkim, Assam, and Meghalaya (Table 1). The samples consisted of 6 collections of $Z$. officinale, 5 collections of $Z$. montanum and 5 collec- 
tions of $Z$. zerumbet. Voucher specimens of all samples are preserved at the Central National Herbarium (CAL), Botanical Survey of India, Howrah, for future reference.

\begin{tabular}{|c|c|c|c|c|c|c|}
\hline S1 No. & Name of the plant & $\begin{array}{l}\text { Common } \\
\text { name }\end{array}$ & Family & $\begin{array}{l}\text { Latitude, longitude } \\
\text { and elevation }\end{array}$ & $\begin{array}{l}\text { Place of } \\
\text { collection }\end{array}$ & Date of collection \\
\hline 1 & $\begin{array}{l}\text { Zingiber officinale } \\
\text { Roscoe }\end{array}$ & $\begin{array}{l}\text { Garden } \\
\text { ginger }\end{array}$ & Zingiberaceae & $\begin{array}{l}26^{\circ} 22^{\prime} \mathrm{N} \\
89^{\circ} 29^{\prime} \mathrm{E} \\
45 \mathrm{~m}\end{array}$ & $\begin{array}{l}\text { Kamat Abutara, } \\
\text { Coochbehar, } \\
\text { West Bengal }\end{array}$ & 20.03 .2010 \\
\hline 2 & $\begin{array}{l}\text { Zingiber officinale } \\
\text { Roscoe }\end{array}$ & $\begin{array}{l}\text { Garden } \\
\text { ginger }\end{array}$ & Zingiberaceae & $\begin{array}{l}26^{\circ} 32^{\prime} \mathrm{N} \\
88^{\circ} 46^{\prime} \mathrm{E} \\
75 \mathrm{~m}\end{array}$ & $\begin{array}{l}\text { Uttar Balaguri, } \\
\text { Dist-Jalpaiguri, } \\
\text { West Bengal }\end{array}$ & 20.03 .2010 \\
\hline 3 & $\begin{array}{l}\text { Zingiber officinale } \\
\text { Roscoe }\end{array}$ & $\begin{array}{l}\text { Garden } \\
\text { ginger }\end{array}$ & Zingiberaceae & $\begin{array}{l}26^{\circ} 22^{\prime} \mathrm{N} \\
89^{\circ} 29^{\prime} \mathrm{E} \\
45 \mathrm{~m}\end{array}$ & $\begin{array}{l}\text { Tufanganj Bazar, } \\
\text { Coochbehr, West Bengal } \\
\text { Source-Bhutan }\end{array}$ & 20.03 .2010 \\
\hline 4 & $\begin{array}{l}\text { Zingiber officinale } \\
\text { Roscoe }\end{array}$ & $\begin{array}{l}\text { Garden } \\
\text { ginger }\end{array}$ & Zingiberaceae & $\begin{array}{l}26^{\circ} 32^{\prime} \mathrm{N} \\
88^{\circ} 46^{\prime} \mathrm{E} \\
75 \mathrm{~m}\end{array}$ & $\begin{array}{l}\text { Birpara market, } \\
\text { Dist-Jalpaiguri, } \\
\text { West Bengal }\end{array}$ & 20.03 .2010 \\
\hline 5 & $\begin{array}{l}\text { Zingiber officinale } \\
\text { Roscoe }\end{array}$ & $\begin{array}{l}\text { Garden } \\
\text { ginger }\end{array}$ & Zingiberaceae & $\begin{array}{l}26^{\circ} 49^{\prime} \mathrm{N} \\
87^{\circ} 49^{\prime} \mathrm{E} \\
53 \mathrm{~m}\end{array}$ & $\begin{array}{l}\text { North Dinajpur Dist, } \\
\text { Old Alluvial zone, } \\
\text { West Bengal }\end{array}$ & 20.03 .2010 \\
\hline 6 & $\begin{array}{l}\text { Zingiber officinale } \\
\text { Roscoe }\end{array}$ & $\begin{array}{l}\text { Garden } \\
\text { ginger }\end{array}$ & Zingiberaceae & $\begin{array}{l}23^{\circ} 80^{\prime} \mathrm{N} \\
93^{\circ} 30^{\prime} \mathrm{E} \\
790 \mathrm{~m}\end{array}$ & $\begin{array}{l}\text { Chajing, } 10 \mathrm{~km} \\
\text { from Imphal, } \\
\text { Manipur }\end{array}$ & 19.04 .2010 \\
\hline 7 & $\begin{array}{l}\text { Zingiber montanum } \\
\text { (J. Koeing) Link ex } \\
\text { A. Dietr }\end{array}$ & $\begin{array}{l}\text { Cassumunar } \\
\text { ginger }\end{array}$ & Zingiberaceae & $\begin{array}{l}27^{\circ} 15^{\prime} \mathrm{N} \\
88^{\circ} 35^{\prime} \mathrm{E} \\
922 \mathrm{~m}\end{array}$ & $\begin{array}{l}\text { East District, } \\
\text { Aau, Sikkim }\end{array}$ & 01.09 .2010 \\
\hline 8 & $\begin{array}{l}\text { Zingiber montanum } \\
\text { (J. Koeing) Link ex } \\
\text { A. Dietr }\end{array}$ & $\begin{array}{l}\text { Cassumunar } \\
\text { ginger }\end{array}$ & Zingiberaceae & $\begin{array}{l}27^{\circ} 15^{\prime} \mathrm{N} \\
88^{\circ} 35^{\prime} \mathrm{E} \\
922 \mathrm{~m}\end{array}$ & $\begin{array}{l}\text { East District, } \\
\text { Aau, Sikkim }\end{array}$ & 01.09 .2010 \\
\hline 9 & $\begin{array}{l}\text { Zingiber montanum } \\
\text { (J. Koeing) Link ex } \\
\text { A. Dietr }\end{array}$ & $\begin{array}{l}\text { Cassumunar } \\
\text { ginger }\end{array}$ & Zingiberaceae & $\begin{array}{l}27^{\circ} 15^{\prime} \mathrm{N} \\
88^{\circ} 35^{\prime} \mathrm{E} \\
922 \mathrm{~m}\end{array}$ & $\begin{array}{l}\text { East District, } \\
\text { Aau, Sikkim }\end{array}$ & 01.09 .2010 \\
\hline 10 & $\begin{array}{l}\text { Zingiber montanum } \\
\text { (J. Koeing) Link ex } \\
\text { A. Dietr }\end{array}$ & $\begin{array}{l}\text { Cassumunar } \\
\text { ginger }\end{array}$ & Zingiberaceae & $\begin{array}{l}27^{\circ} 15^{\prime} \mathrm{N} \\
88^{\circ} 35^{\prime} \mathrm{E} \\
922 \mathrm{~m}\end{array}$ & $\begin{array}{l}\text { East District, } \\
\text { near Aau, Sikkim }\end{array}$ & 11.05 .2009 \\
\hline 11 & $\begin{array}{l}\text { Zingiber montanum } \\
\text { (J. Koeing) Link ex } \\
\text { A. Dietr }\end{array}$ & $\begin{array}{l}\text { Cassumunar } \\
\text { ginger }\end{array}$ & Zingiberaceae & $\begin{array}{l}27^{\circ} 15^{\prime} \mathrm{N} \\
88^{\circ} 35^{\prime} \mathrm{E} \\
922 \mathrm{~m}\end{array}$ & $\begin{array}{l}\text { East District, } \\
\text { near Aau, Sikkim }\end{array}$ & 11.05 .2009 \\
\hline 12 & $\begin{array}{l}\text { Zingiber zerumbet } \\
\text { (L.) Roscoe ex Sm }\end{array}$ & $\begin{array}{l}\text { Shampoo } \\
\text { ginger }\end{array}$ & Zingiberaceae & $\begin{array}{l}27^{\circ} 11^{\prime} \mathrm{N} \\
88^{\circ} 36^{\prime} \mathrm{E} \\
512 \mathrm{~m}\end{array}$ & $\begin{array}{l}\text { East District, } \\
\text { near Rongli, } \\
\text { Sikkim }\end{array}$ & 05.09 .2010 \\
\hline 13 & $\begin{array}{l}\text { Zingiber zerumbet } \\
\text { (L.) Roscoe ex Sm }\end{array}$ & $\begin{array}{l}\text { Shampoo } \\
\text { ginger }\end{array}$ & Zingiberaceae & $\begin{array}{l}25^{\circ} 40^{\prime} \mathrm{N} \\
91^{\circ} 54^{\prime} \mathrm{E} \\
973 \mathrm{~m}\end{array}$ & $\begin{array}{l}\text { East Khasi Hills, } \\
\text { Barapani, Meghalaya }\end{array}$ & 14.07 .2010 \\
\hline 14 & $\begin{array}{l}\text { Zingiber zerumbet } \\
\text { (L.) Roscoe ex Sm }\end{array}$ & $\begin{array}{l}\text { Shampoo } \\
\text { ginger }\end{array}$ & Zingiberaceae & $\begin{array}{l}25^{\circ} 40^{\prime} \mathrm{N} \\
91^{\circ} 54^{\prime} \mathrm{E} \\
969 \mathrm{~m}\end{array}$ & $\begin{array}{l}\text { East Khasi Hills, } \\
\text { Barapani, Meghalaya }\end{array}$ & 12.07 .2010 \\
\hline 15 & $\begin{array}{l}\text { Zingiber zerumbet } \\
\text { (L.) Roscoe ex Sm }\end{array}$ & $\begin{array}{l}\text { Shampoo } \\
\text { ginger }\end{array}$ & Zingiberaceae & $\begin{array}{l}24^{\circ} 50^{\prime} \mathrm{N} \\
93^{\circ} 20^{\prime} \mathrm{E} \\
356 \mathrm{~m}\end{array}$ & $\begin{array}{l}\text { Lakhipur, } 45 \mathrm{~km} \text { from } \\
\text { Silchar, Assam }\end{array}$ & 26.04 .2010 \\
\hline 16 & $\begin{array}{l}\text { Zingiber zerumbet } \\
\text { (L.) Roscoe ex Sm }\end{array}$ & $\begin{array}{l}\text { Shampoo } \\
\text { ginger }\end{array}$ & Zingiberaceae & $\begin{array}{l}23^{\circ} 43^{\prime} \mathrm{N} \\
92^{\circ} 23^{\prime} \mathrm{E} \\
300 \mathrm{~m}\end{array}$ & $\begin{array}{l}\text { Karimganj, } 54 \text { km from } \\
\text { Silchar, Assam }\end{array}$ & 05.05 .2010 \\
\hline
\end{tabular}

\section{DNA extraction}

Genomic DNA from all plant samples was isolated from young leaves from each genotype. Total genomic DNA was extracted using the Qiagen total plant DNA extraction kit. The concentration of DNA in the samples was determined by the 260/280 O.D. value. The DNA samples were subjected to $0.8 \%$ agarose gel electrophoresis; genomic $\lambda$ DNA $(25 \mathrm{ng} / \mu \mathrm{L})$ was used 
as standard. All DNA samples taken for AFLP study showed a 260/280 O.D. value of 1.75-2.00.

\section{AFLP fingerprinting}

AFLP electropherograms were produced for each variety using the ABI prism fluorescent dye labeling and detection technology (Perkin-Elmer). AFLP analysis was performed using the kit supplied by Applied Biosystems (USA) and was used according to manufacturer instructions.

High-quality genomic DNA (500 ng) was digested with $1 \mathrm{U}$ MseI and $5 \mathrm{U}$ EcoRI restriction endonucleases. EcoRI and MseI adaptors were ligated with 1 UT4 DNA ligase (all enzymes were from New England Biolabs, Beverly, MA, USA). Restriction and ligation were done simultaneously (Vos et al., 1995) in a single step by incubating at $37^{\circ} \mathrm{C}$ for $2 \mathrm{~h}$ in a thermocycler (Applied Biosystems).

Polymerase chain reaction (PCR) amplification and selective amplification were carried out according to instructions provided in the kit. Pre-amplifications were evaluated running preamplified samples on a 1.5\% agarose gel. A smear of product from 100-1500 bp was clearly visible.

Selective amplification was carried out using seven primer pairs for three species of the Zingiber genus, viz., Z. officinale Roscoe, Z. montanum (J. Koeing) Link ex A. Dietr and $Z$. zerumbet (L.) Roscoe ex Sm. The amplified products were mixed with Size Standard Gene Scan 500 ROX, and the samples were then analyzed on an automated DNA sequencer (ABI Model 3130 XL genetic analyzer, Applied Biosystems).

\section{Scoring and data analysis}

Fragment analysis was carried out for bands in the range of 35-500 bp. For diversity analysis, bands were scored as presence (1) or absence (0) to form a raw data matrix. A square symmetric matrix of similarity was then obtained with the Jaccard's similarity coefficient (Jaccard, 1908). The average similarity matrix was used to generate a tree for cluster analyses by UPGMA (unweighted pair group method with arithmetic mean) using the NTSys v 2.1 software.

\section{RESULTS AND DISCUSSION}

In the present study, seven pairs of primer pairs were used in AFLP fingerprinting for all landraces (of three species of the Zingiber genus, viz., Z. officinale, Z. montanum and $Z$. zerumbet). Of a total of 837 peaks, only 2 peaks were monomorphic and 835 were polymorphic. A polymorphism of $99.7 \%$ was detected among the species.

The study could identify species-specific AFLP markers for the three Zingiber species, where all landraces within a single species showed similarity in pattern. The AFLP alleles common to all the landraces of $Z$. officinale, using seven primer pairs, and their respective size of alleles in bp are shown in Table 2. Similarly, alleles, specific for Z. montanum and Z. zerumbet with their respective size (in bp) are shown in Table 3 and Table 4, respectively. Such data on DNA characterization reveal variation among the three species, landraces of each species being similar regardless of their place of collection. This suggests that DNA fingerprinting (by AFLP) may be used as a dependable identifying parameter for species identification even if collected from different locations, at least within the range of distance of this collection. The fact that this study relates to the study of leaves also establishes that in DNA fingerprinting methods flowers are not essential for plant identification as is needed for classical taxonomic studies. Some representative AFLP patterns of the three species are given in Figures 1A-C and 2A-C. 


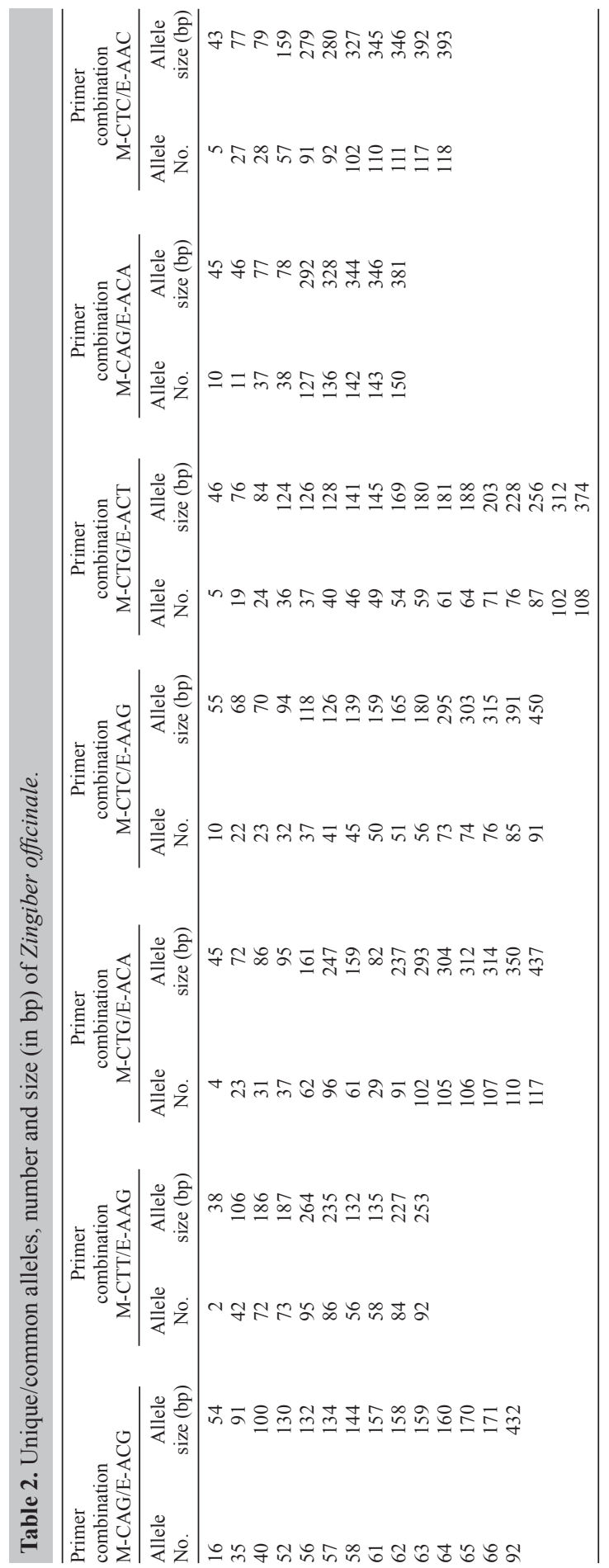




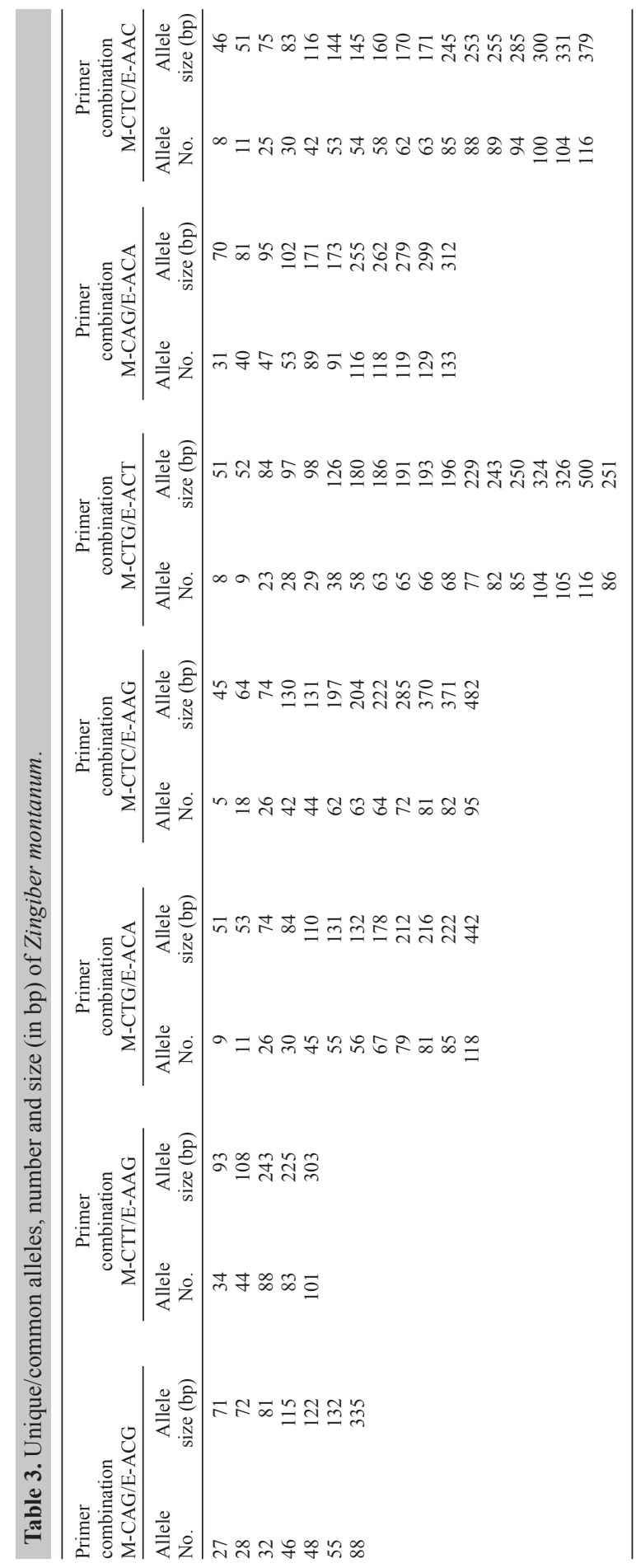




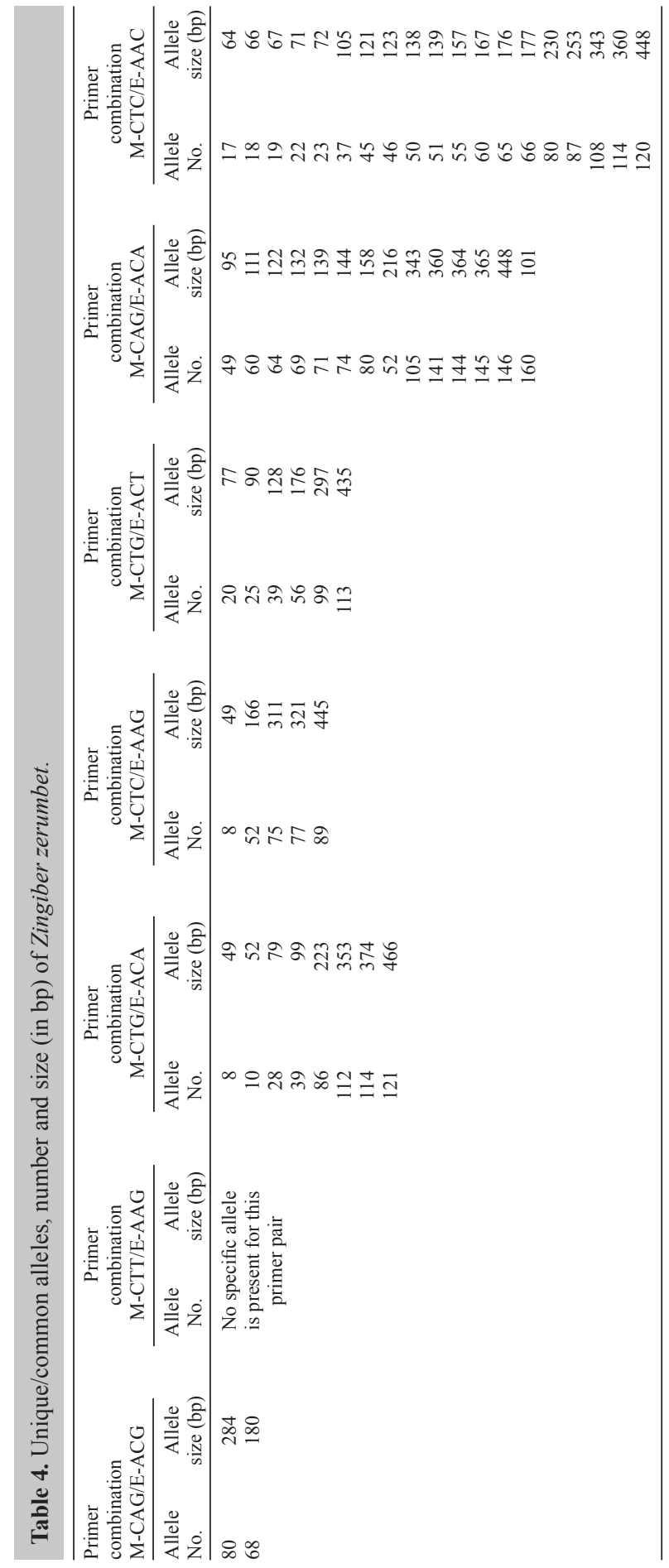



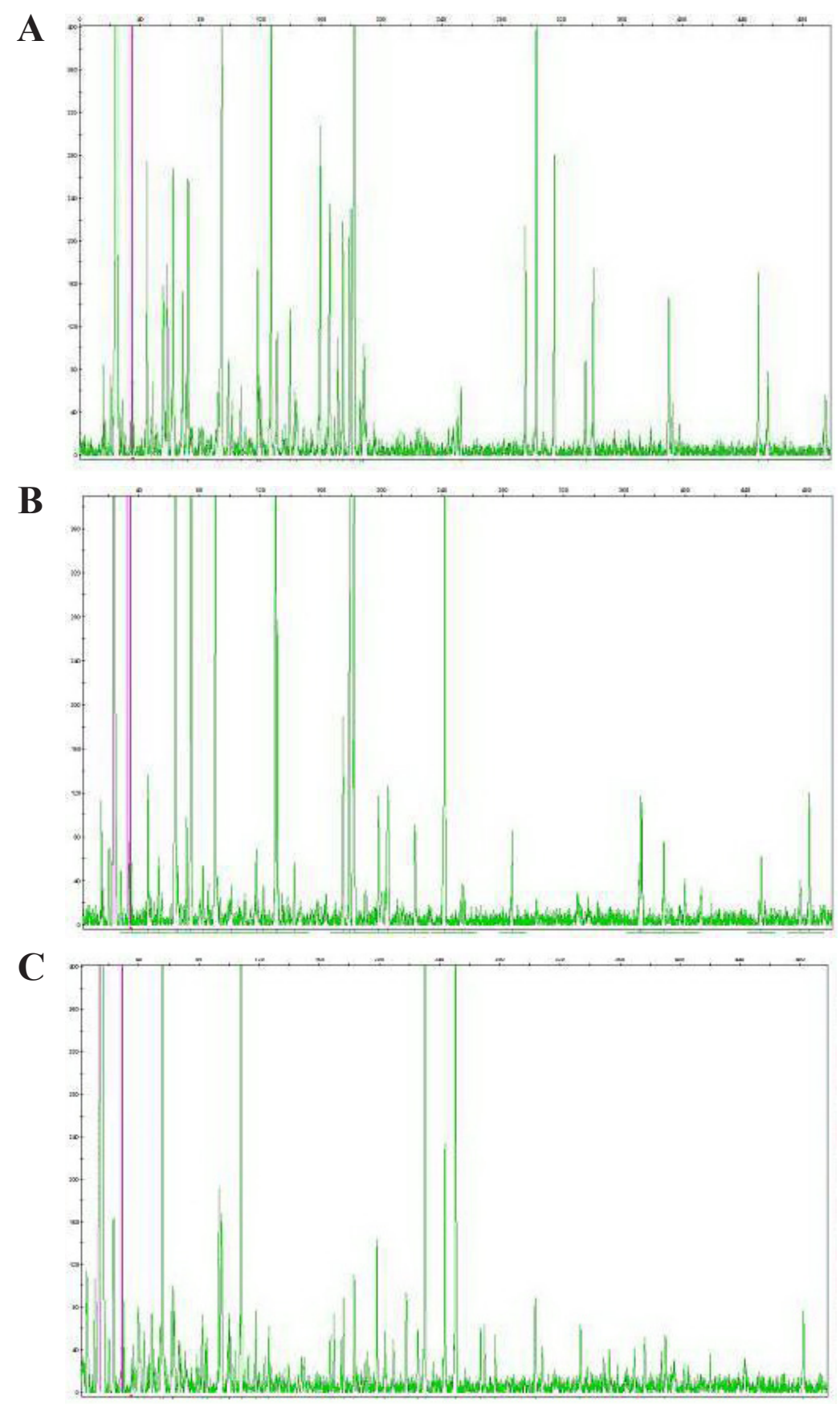

Figure 1. A. AFLP patterns of Zingiber officinale using primer pairs EcoRI-AAG and MseI-CTC. B. AFLP patterns of $Z$. montanum using primer pairs EcoRI-AAG and MseI-CTC. C. AFLP patterns of $Z$. zerumbet using primer pairs EcoRI-AAG and MseI-CTC. X-axis = base pair of alleles; Y-axis = intensity of alleles. 
AFLP markers for identification of three Zingiber species

A

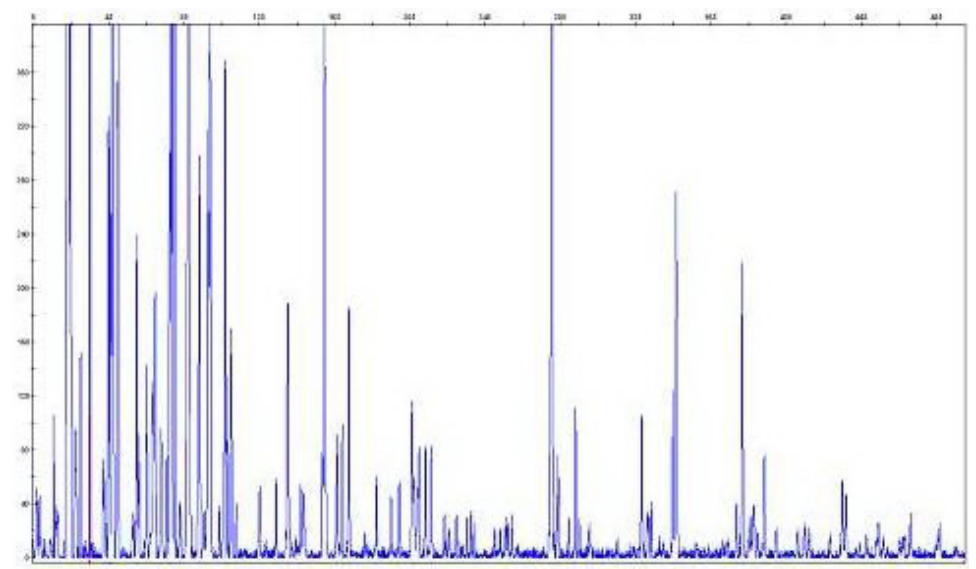

B

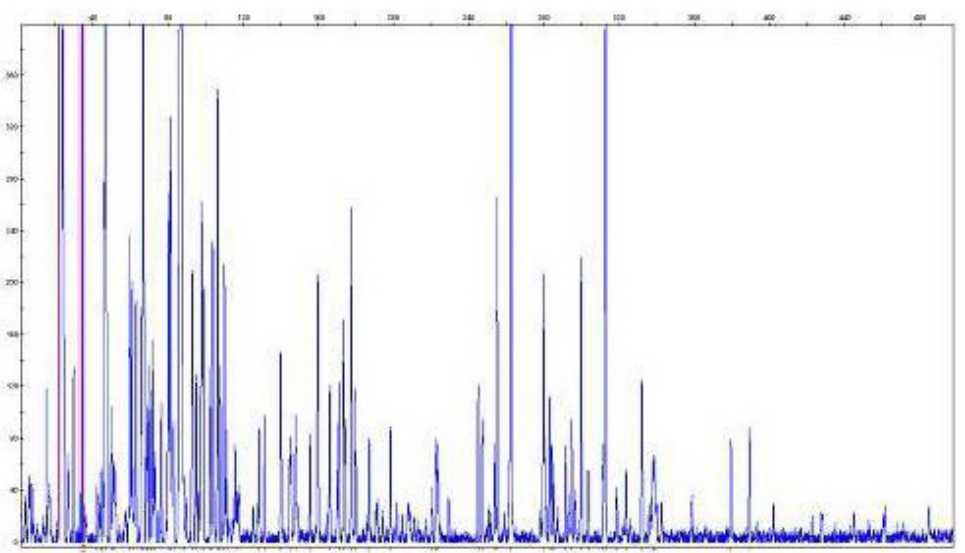

C

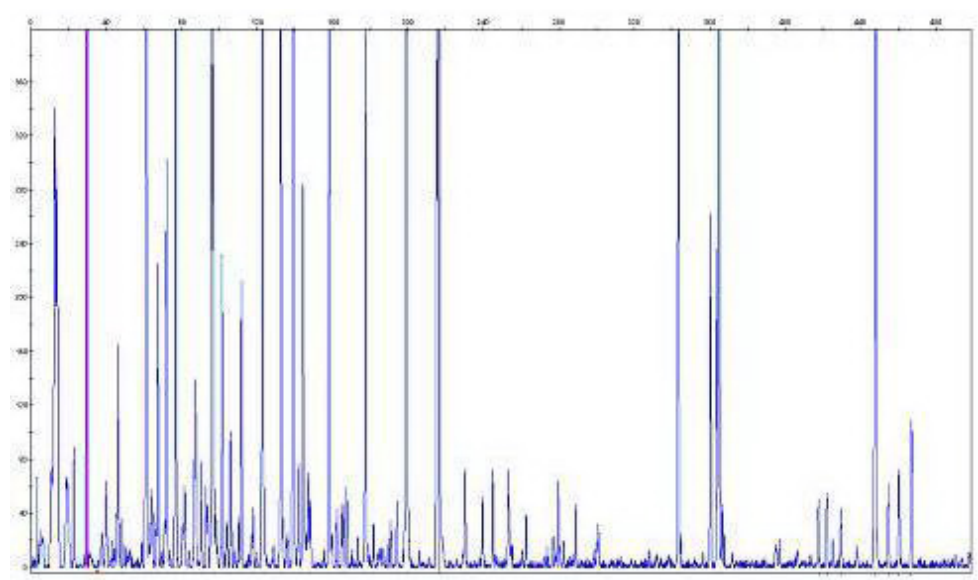

Figure 2. A. AFLP patterns of Zingiber officinale using primer pairs EcoRI-ACA and MseI-CAG. B. AFLP patterns of Z. montanum using primer pairs EcoRI-ACA and MseI-CAG. C. AFLP patterns of Z. zerumbet using primer pairs EcoRI-ACA and MseI-CAG. X-axis = base pair of alleles; Y-axis = intensity of alleles. 
The dendogram obtained after analysis using the NTSys v 2.1 software indicated 3 major clusters, each representing one of the 3 different species of the Zingiber genus used in the study (Figure 3). In the first cluster, six landraces of $Z$. officinale clustered together, showing $92.5 \%$ similarity among them. The second group consisted of five landraces of the Z. montanum grouping together with $95 \%$ similarity within the cluster. Similarly, in the third group, five landraces of $Z$. zerumbet clustered together with $95.5 \%$ similarity within them. From this dendogram, it appears that $Z$. montanum and $Z$. zerumbet are phylogenetically more closely linked to each other than to $Z$. officinale.

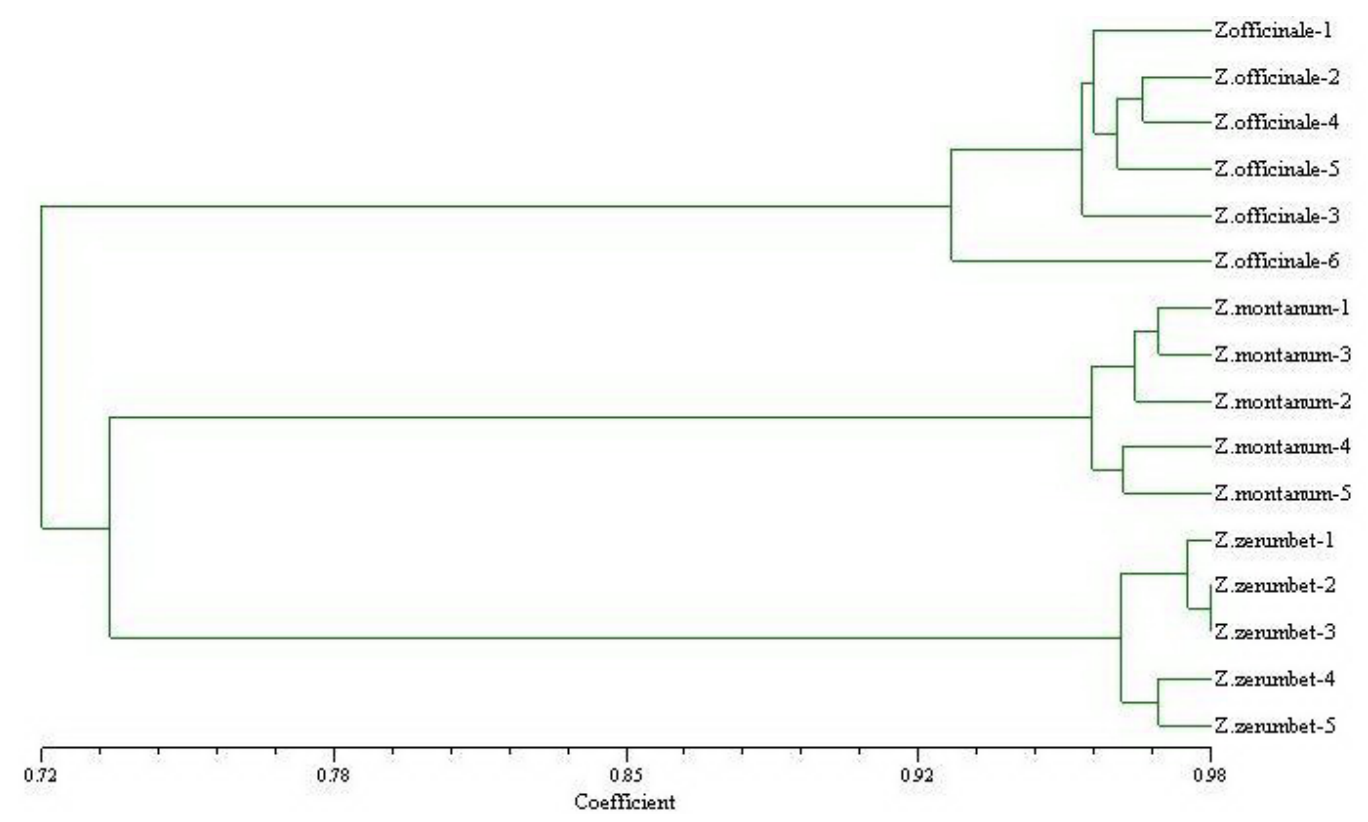

Figure 3. Cluster diagram showing relationship among three Zingiber species.

The DNA molecular markers represented by unique peaks for each of the three species of the Zingiber genus generated in the present study suggest these as a useful reference tool for species identification that circumvents problems associated with morphological or biochemical markers. The frequency of occurrence of unique peaks in AFLP analysis of DNA isolated from crude drug (plant) preparation (Misra et al., 2007) could be used to assay for the presence of a specific species population. AFLP, in particular, has been the method of choice for discriminating between closely related species and authentication of herbs, as demonstrated for the Plectranthus genus in an earlier study (Passinho-Soares et al., 2006). In the present study, too, a well-defined grouping pattern was obtained for the three Zingiber species analyzed. The significance of this study stems from the fact that it provides an authentication tool to detect adulterants in the crude drug preparations and to maintain the quality standards in the herbal drug industry.

\section{ACKNOWLEDGMENTS}

Research supported by the Indian Council of Medical Research (ICMR): project 
"Centre for advanced research in DNA fingerprinting and diagnostics of medicinal potential in plants from eastern and northeastern India" operative at Bose Institute, Kolkata. One of the authors (S. Ghosh) is grateful to ICMR for an ad hoc fellowship. Authors wish to thank the Director, Botanical Survey of India (BSI) for providing plant collection and herbarium support and Meghalaya and Sikkim Forest Department for their help during plant collection by BSI. The authors also thank Dr. Sekhar Bandhopadhyay, Lecturer, North Bengal Agricultural University, for providing some of the experimental Zingiber officinale plant materials.

\section{REFERENCES}

Degani C, Rowland LJ, Saunders JA, Hokanson SC, et al. (2001). A comparison of genetic relationship measures in strawberry (Fragaria ananassa Duch.) based on AFLP's, RAPD's, and pedigree data. Euphytica 117: 1-12.

Jaccard P (1908). Nouvelles recherches sur la distribution florale. Bull. Soc. Vaudoise Sci. Nat. 44: 223-270.

Joshi K, Chavan P, Warude D and Patwardhan B (2004). Molecular marker in herbal drug technology. Curr. Sci. 87: 159-165.

Lin JJ, Kuo J, Ma J, Saunders JA, et al. (1996). Identification of molecular markers in soybean comparing RFLP, RAPD and AFLP DNA mapping techniques. Plant Mol. Biol. Rep. 14: 156-169.

Misra A, Shasany AK, Shukla AK, Sundaresan V, et al. (2007). AFLP-based detection of adulterants in crude drug preparations of the 'Safed Musli' complex. Nat. Prod. Comm. 2: 93-97.

Misra A, Shasany AK, Shukla AK, Darokar MP, et al. (2010). AFLP markers for identification of Swertia species (Gentianaceae). Genet. Mol. Res. 9: 1535-1544.

Passinho-Soares H, Felix D, Kaplan MA, Margis-Pinheiro M, et al. (2006). Authentication of medicinal plant botanical identity by amplified fragmented length polymorphism dominant DNA marker: inferences from the Plectranthus genus. Planta Med. 72: 929-931.

Percifield RJ, Hawkins JS, McCoy JA, Widrlechner MP, et al. (2007). Genetic diversity in Hypericum and AFLP markers for species-specific identification of H. perforatum L. Planta Med. 73: 1614-1621.

Saunders JA, Pedroni MJ and Daughtry CS (1999). DNA fingerprinting of marijuana by the AFLP technique. Focus 20: 10-11. Saunders JA, Pedroni MJ, Penrose L and Fist AJ (2001). AFLP DNA analysis of opium Poppy. Crop Sci. 41: 1596-1601.

Vos P, Hogers R, Bleeker M, Reijans M, et al. (1995). AFLP: a new technique for DNA fingerprinting. Nucleic Acids Res. 23: 4407-4414.

Waugh R, Bonar N, Baird E, Thomas B, et al. (1997). Homology of AFLP products in three mapping populations of barley. Mol. Gen. Genet. 255: 311-321. 